\title{
AN ATTEMPT TO IDENTIFY SOCIAL - ECONOMIC FACTORS IN THE LEVELS OF PROPERTY PRICES IN CHOSEN CITIES IN POLAND
}

\author{
Sebastian Kokot, assoc. prof., PhD \\ Faculty of Economics and Management \\ University of Szczecin \\ e-mail: sebastian.kokot@usz.edu.pl
}

\begin{abstract}
Property prices vary on different local real estate markets. Even considering only the largest cities, great disproportions between average unit prices can easily be observed. This problem involves all segments of the real estate market, yet, because of the social \& economic importance of housing properties, it takes on special importance on the apartment market. In Warsaw - the capital of Poland and the largest Polish city - prices exceed PLN 10,000 per $1 \mathrm{~m}^{2}$ in the best locations and the average price at the end of 2016 in the entire city came to over PLN 7,500 per $1 \mathrm{~m}^{2}$. At the sme time, however, average prices in other agglomerations, such as Łódź or Katowice, were equal to approx. PLN 3,500 per $1 \mathrm{~m}^{2}$. It is only natural to ask what factors, especially social \& economic, contribute to such considerable differences in house prices. This article addresses a group of potential factors underlying the prices of apartments, which have been studied statistically in correlation with average unit prices of apartments in chosen cities.
\end{abstract}

Key words: real estate market, prices of apartments, apartment price factors.

JEL Classification: $R 20$.

Citation: Kokot S., 2018, An Attempt to Identify Social - Economic Factors in the Levels of Property Prices in Chosen Cities in Poland, Real Estate Management and Valuation, vol. 26, no. 3, pp. 93-104.

DOI: $10.2478 /$ remav-2018-0028

\section{Introduction}

The value and, in consequence, the price of a property obtained on the market stems from a range of factors of an economic and social character. Typical, durable factors of property prices, in particular apartments, include - apart from the costs of construction - economic and social factors, such as household income, population increase, employment and interest rates (HWANG QUIGLEY 2006). The term real estate market has many definitions based on different ways of perceiving and observing phenomena on that market and giving emphasis to different aspects of the market's functioning, e.g. subjective, objective, economic, legal, geographical, institutional, technical and technological (more inter alia: BALL LIZIERI MACGREGOR 1998; KUCHARSKA-STASIAK 2006; STACHURA 2007; WIŚNIEWSKA 2011). One of the possible approaches when attempting to arrange and classify such definitions is to outline three main categories or perspectives of perceiving the real estate market, i.e. macro, micro and ultra. Each category is associated with a particular milieu consisting of relevant factors (MACH 2014). Such classification helps to define the surveyed matter, though it happens to be understood in different ways. The real estate market (or a particular real estate sector - e.g. sector of apartments) in a macro approach is the market relating to the national economy. Crucial elements of its surroundings include, in particular, the legal system, GDP, inflation, loan interest rates and deposit rates, average unemployment rate, loan availability, average income, property taxes and property transaction taxes, freedom in property trade, governmental programmes supporting the construction industry, systems 
for securing housing needs of the population (co-op flats, council flats, etc.), certain cultural elements (e.g. average age of young people becoming independent, co-housing in multi-generation families, etc.), economic prosperity and economic cycles. Therefore, attention is given to elements common for the entire national economy, the whole country. When analyzing the real estate market in macro terms, certain aspects of the real estate market in different countries are compared (EGERT MIHALJEK 2007). Macro-economic effects, including economic crises, play a critical role here (STROBEL THANH LEE 2018).

In consequence, those analyses bear a rough character and refer to estimated and averaged parameters. Perceiving the real estate market in micro terms means that its local features, which are characteristic for a particular area, are considered. These features may include, in particular, the population of an area (e.g. city), unemployment rate in the region, personal income in the region, the broadly understood attractiveness of the region (including touristic attractiveness, quality of the transport service (quality and density of roads, railway connections, urban transport, bike routes), availability and quality of cultural and sports amenities, and other factors (quantifiers) characterising the region's economic growth, e.g. city revenues, number of enterprises, number of apartments vs population, etc. Factors common for the entire national economy, such as interest rates of mortgage loans, which are practically identical in every part of the country, are therefore excluded. In practice, considerable differentiation of property prices is observed on local markets (LAI ORDER 2017; BLACK FRASER HOESLI 2006). Then again, when referring to the market in ultra-terms, focus is given to its very local features and factors. Fashionable locations in respective districts (fashionable and unfashionable districts in a given city), the form of development, a functional layout of apartments, the location in the building and with reference to directions of the world, the commute to the apartment and to the city center, the area of the apartments, the finishing standard and the technical condition of the building, environs and the neighbourhood, etc. are important in this aspect. These are factors which property experts consider when evaluating the property, assuming that factors perceived in macro and micro categories are constant on a given local market. Analyses of the differentiation of prices between the city centre and suburbs are an example of studies in this respect (compare RAcKA et al. 2017). Considering such perspectives of perceiving the real estate market, the further parts of this article identify a group of potential factors of housing prices in micro terms and statistically study their correlation with average unit prices of apartments in chosen cities. The surveys aimed to find an answer to the question as to whether differences in the level of prices of apartments in metropolitan areas stem from differences in local social \& economic conditions, or perhaps from elsewhere. Thus far, surveys on the impact of these factors on the prices of apartments and the development of the housing market understood more broadly do not provide grounds for formulating any explicit conclusions (inter alia CAPOZZA et al. 2002; FORYŚ 2013).

\section{Statistical data and the survey method}

The framework of the survey was determined largely by the availability of statistical data. Data from two sources were used for the survey:

1. Data provided by the National Bank of Poland comprising average transaction prices per square metre of an apartment on the secondary market for 16 capital cities of voivodeships and Gdynia on a quarterly basis, in the $4^{\text {th }}$ quarter of 2016. Such data in xls format had been uploaded from the website of the National Bank of Poland.

2. Data provided by the Main Statistical Office through a Local Data Bank. This source provided data regarding:

- the population according to the current place of residence in the cities as of 31 December 2016 [persons],

- unemployment rate in cities in 2016 [\%],

- city revenues in total in 2016 [PLN],

- number of apartments in cities as of 31 December 2016 [apartments],

- usable surface of apartments in cities as of 31 December $2016\left[\mathrm{~m}^{2}\right]$,

- average gross monthly remuneration in cities (without business entities with up to 9 employees) in 2016 [PLN].

For the purpose of the survey, the number of apartments was expressed in thousands, whereas the usable surface in millions of square metres.

Based on the data obtained, the following was calculated: 
- revenues of gmina per person;

- average number of persons per apartment (population/number of apartments).

Some among the specified variables may be considered disputable, e.g. city revenues. However, it is not the fact that city revenues have direct impact on the price levels, but to some extent (not specified in detail) city revenues reflect the city's level of growth and become an indicator of such growth. This approach is often applied in surveys regarding economic occurrences, among which part can hardly be gauged or cannot be gauged directly at all.

The survey included cities with powiat (district) rights: Białystok, Bydgoszcz, Gdańsk, Gdynia, Katowice, Kielce, Kraków, Lublin, Łódź, Olsztyn, Opole, Poznań, Rzeszów, Szczecin, Warsaw, Wrocław and Zielona Góra. The data gathered and used in the survey are presented in Table 1, which also shows the variation coefficients of the particular variables.

Table 1

Statistical data

\begin{tabular}{|c|c|c|c|c|c|c|c|c|c|}
\hline City & 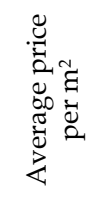 & $\begin{array}{l}\frac{0}{0} \\
\frac{0}{0} \\
\frac{\pi}{3} \\
0 \\
0 \\
0\end{array}$ & 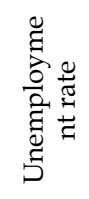 & 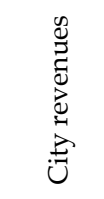 & 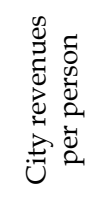 & 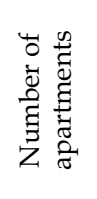 & 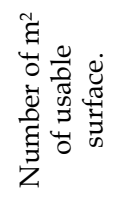 & 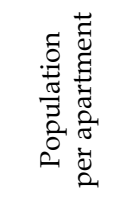 & 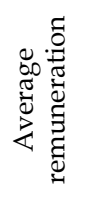 \\
\hline Białystok & 4078 & 296628 & 9.0 & 1566 & 5285 & 128 & 7.82 & 2.3158 & 3968 \\
\hline Bydgoszcz & 3782 & 353938 & 4.8 & 1782 & 5019 & 149 & 8.62 & 2.3770 & 3951 \\
\hline Gdańsk & 5610 & 463754 & 3.6 & 2794 & 6035 & 216 & 12.83 & 2.1461 & 5119 \\
\hline Gdynia & 5141 & 246991 & 4.0 & 1362 & 5506 & 112 & 6.91 & 2.2038 & 4799 \\
\hline Katowice & 3577 & 298111 & 2.8 & 1753 & 5862 & 143 & 8.57 & 2.0894 & 5275 \\
\hline Kielce & 3456 & 197704 & 7.7 & 1114 & 5634 & 84 & 4.90 & 2.3636 & 3920 \\
\hline Kraków & 5951 & 765320 & 3.6 & 4650 & 6099 & 369 & 21.31 & 2.0729 & 635 \\
\hline Lublin & 4680 & 340466 & 7.2 & 1833 & 5380 & 150 & 8.98 & 2.2773 & 4169 \\
\hline Łódź & 3417 & 696503 & 7.9 & 3908 & 5594 & 354 & 19.14 & 1.9677 & 4230 \\
\hline Olsztyn & 4125 & 172993 & 5.1 & 1037 & 5974 & 77 & 4.46 & 2.2560 & 4255 \\
\hline Opole & 3935 & 118722 & 4.9 & 730 & 6136 & 52 & 3.43 & 2.2790 & 4378 \\
\hline Poznań & 5282 & 540372 & 1.9 & 3253 & 6007 & 254 & 16.41 & 2.1268 & 4771 \\
\hline Rzeszów & 4642 & 187422 & 6.8 & 1058 & 5658 & 77 & 5.12 & 2.4461 & 4319 \\
\hline Szczecin & 4000 & 404878 & 4.7 & 2252 & 5555 & 175 & 11.19 & 2.3114 & 4539 \\
\hline Warszawa & 7556 & 1753977 & 2.8 & 14722 & 8418 & 933 & 54.92 & 1.8808 & 5740 \\
\hline Wrocław & 5480 & 637683 & 2.8 & 4039 & 6340 & 311 & 21.74 & 2.0504 & 4801 \\
\hline Ziel. Góra & 3073 & 139330 & 4.7 & 720 & 5187 & 59 & 4.11 & 2.3736 & 3920 \\
\hline Vs & 0.24 & 0.84 & 0.41 & 1.12 & 0.12 & 0.95 & 0.92 & 0.07 & 0.11 \\
\hline $\begin{array}{c}\text { Vs without } \\
\text { Warsaw }\end{array}$ & 0.20 & 0.54 & 0.39 & 0.57 & 0.06 & 0.59 & 0.58 & 0.06 & 0.09 \\
\hline
\end{tabular}

Source: NBP and GUS.

In the further part of this study, data regarding the average price per $\mathrm{m}^{2}$ in cities were adopted as the dependant variable, while the remaining data were treated as independent variables representing three groups of partially intertwining factors that could potentially determine the prices of apartments in respective cities, i.e.:

1. Factors regarding the size of the municipal area (population, number of apartments, city revenues, number of $\mathrm{m}^{2}$ of usable surface),

2. Factors of economic development and wealth of the city (city revenues, city revenues per person),

3. Factors regarding the wealth and quality of life of the residents (unemployment rate, number of persons per apartment, average remuneration).

The survey was conducted on a cross-sectional basis by way of:

1. Calculating coefficients of Pearson's linear correlation between all variables (correlation table),

2. Collerograms (charts of dispersion) of an average unit price of apartments in respective cities vs 
respective social \& economic factors reflected by variables constituting the said data,

3. Estimating, for every relation, the average unit price of apartments in respective cities in terms of respective social \& economic factors of linear and non-linear regression functions. The analytical form of the non-linear function was matched based on a visual examination of collerograms.

For better viewing of the results, the paths of estimated functions of a single regression (see Section 2) have been marked on the collerograms.

Since it transpired after the surveys had been performed that the results could be distorted significantly by data regarding Warsaw, the entire survey was repeated, but with the said data eliminated.

\section{Results of studies}

Table 2 presents the Pearson correlation coefficients between average prices of apartments in respective cities and the studied variables, and between the variables. Table 3 presents similar coefficients calculated based on data excluding Warsaw.

Table 2

Correlations between studied variables

\begin{tabular}{|c|c|c|c|c|c|c|c|c|c|}
\hline & $\stackrel{\ddot{E}}{\tilde{E}}$ & 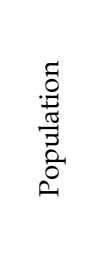 & 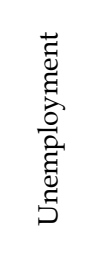 & 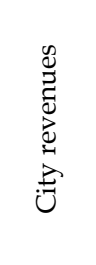 & 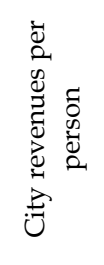 & 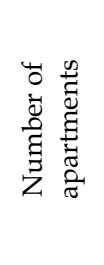 & 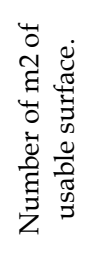 & 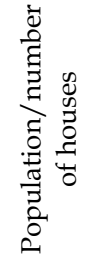 & 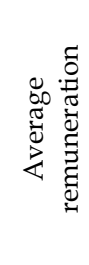 \\
\hline Price & 1.00 & 0.77 & -0.52 & 0.78 & 0.79 & 0.77 & 0.79 & -0.60 & 0.73 \\
\hline Population & 0.77 & 1.00 & -0.36 & 0.99 & 0.84 & 1.00 & 1.00 & -0.79 & 0.66 \\
\hline Unemployment & -0.52 & -0.36 & 1.00 & -0.36 & -0.48 & -0.36 & -0.39 & 0.47 & -0.73 \\
\hline City revenues & 0.78 & 0.99 & -0.36 & 1.00 & 0.89 & 0.99 & 0.99 & -0.74 & 0.68 \\
\hline $\begin{array}{l}\text { City revenues per } \\
\text { person }\end{array}$ & 0.79 & 0.84 & -0.48 & 0.89 & 1.00 & 0.86 & 0.87 & -0.70 & 0.78 \\
\hline $\begin{array}{l}\text { Number of } \\
\text { apartments }\end{array}$ & 0.77 & 1.00 & -0.36 & 0.99 & 0.86 & 1.00 & 1.00 & -0.79 & 0.67 \\
\hline $\begin{array}{l}\text { Number of } \mathrm{m}^{2} \text { of } \\
\text { usable surface }\end{array}$ & 0.79 & 1.00 & -0.39 & 0.99 & 0.87 & 1.00 & 1.00 & -0.79 & 0.69 \\
\hline $\begin{array}{l}\text { Population/ number } \\
\text { of apartments }\end{array}$ & -0.60 & -0.79 & 0.47 & -0.74 & -0.70 & -0.79 & -0.79 & 1.00 & -0.74 \\
\hline $\begin{array}{l}\text { Average } \\
\text { remuneration }\end{array}$ & 0.73 & 0.66 & -0.73 & 0.68 & 0.78 & 0.67 & 0.69 & -0.74 & 1.00 \\
\hline
\end{tabular}

Source: own study.

As shown, the specified variables point to a significant correlation of apartments in respective cities with average prices, yet these correlations are not very high. Similar coefficients calculated for data excluding Warsaw are definitely lower and as regards unemployment and the number of persons per apartment - they are irrelevant. Also, it appears that most variables considered are correlated with each other and, in certain cases, much more than with the average price, which entails another significant issue when identifying price factors, especially pointing to potential problems in attempts to model prices by means of multifarious regression with the use of such variables. 


\section{S sciendo}

Table 3

Correlation between the studied variables excluding Warsaw

\begin{tabular}{|c|c|c|c|c|c|c|c|c|c|}
\hline & $\stackrel{\mathscr{Z}}{\mathscr{2}}$ & 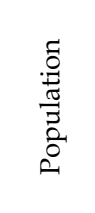 & 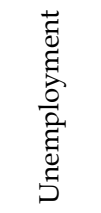 & $\begin{array}{l}\mathscr{D} \\
己 \\
己 \\
0 \\
己 \\
己 \\
D \\
0\end{array}$ & 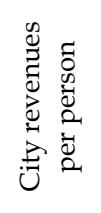 & 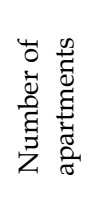 & 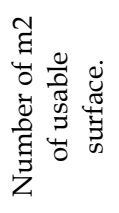 & 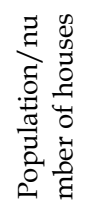 & 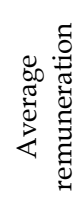 \\
\hline Price & 1.00 & 0.53 & -0.47 & 0.58 & 0.56 & 0.56 & 0.51 & -0.38 & 0.56 \\
\hline Population & 0.53 & 1.00 & -0.26 & 0.99 & 0.36 & 0.99 & 1.00 & -0.78 & 0.35 \\
\hline Unemployment & -0.47 & -0.26 & 1.00 & -0.32 & -0.53 & -0.34 & -0.26 & 0.40 & -0.73 \\
\hline City revenues & 0.58 & 0.99 & -0.32 & 1.00 & 0.45 & 0.99 & 0.99 & -0.80 & 0.40 \\
\hline $\begin{array}{l}\text { City revenues per } \\
\text { person }\end{array}$ & 0.56 & 0.36 & -0.53 & 0.45 & 1.00 & 0.44 & 0.38 & -0.57 & 0.64 \\
\hline $\begin{array}{l}\text { Number of } \\
\text { apartments }\end{array}$ & 0.56 & 0.99 & -0.34 & 0.99 & 0.44 & 1.00 & 0.99 & -0.80 & 0.40 \\
\hline $\begin{array}{l}\text { Number of m2 of } \\
\text { usable surface }\end{array}$ & 0.51 & 1.00 & -0.26 & 0.99 & 0.38 & 0.99 & 1.00 & -0.81 & 0.36 \\
\hline $\begin{array}{l}\text { Population/ number } \\
\text { of apartments }\end{array}$ & -0.38 & -0.78 & 0.40 & -0.80 & -0.57 & -0.80 & -0.81 & 1.00 & -0.62 \\
\hline $\begin{array}{l}\text { Average } \\
\text { remuneration }\end{array}$ & 0.56 & 0.35 & -0.73 & 0.40 & 0.64 & 0.40 & 0.36 & -0.62 & 1.00 \\
\hline
\end{tabular}

Source: own study.

Charts 1-16 below present collerograms (statistical dispersion charts) of the average unit price of apartments in respective cities $\left(\widehat{C}_{l}\right)$ vs. variables reflecting the considered potential factors of those prices, i.e.

- population in cities $\left(x_{1 i}\right)$,

- unemployment rates in cities $\left(x_{2 i}\right)$,

- city revenues $\left(x_{3 i}\right)$,

- city revenues per person $\left(x_{4 i}\right)$,

- number of apartments in cities $\left(x_{5 i}\right)$,

- number of $\mathrm{m}^{2}$ of housing usable surface in cities $\left(x_{6 i}\right)$,

- size of population/number of apartments in cities $\left(x_{7 i}\right)$,

- average remuneration in cities $\left(x_{8 i}\right)$.

Charts with odd numbers comprise data regarding all cities and charts with even numbers pertain to data excluding Warsaw. To better depict the results, the charts presenting the dependence of prices on respective factors including and excluding Warsaw have been shown side by side. Presented below the charts are equations of the estimated functions of single regressions - linear and non-linear, with estimation errors concerning structural parameters and the coefficient of determination $\mathrm{R}^{2}$. Regression functions:

Linear:

Linear excl. Warsaw:

$$
\begin{aligned}
\widehat{C}_{l}= & 3551.84+0.0023 \cdot x_{1 i} \\
& (282.59)(0.0005) \\
\widehat{C}_{l}= & 3548.43+0.0023 \cdot x_{1 i}
\end{aligned}
$$$$
\text { (411.29) (0.0010) }
$$$$
\mathrm{R}^{2}=0.60
$$$$
\mathrm{R}^{2}=0.27
$$$$
\widehat{C}_{\iota}=-10541.17+2727.27 \log 10\left(x_{1 i}\right)
$$$$
\text { (3809.84) (686.39) }
$$$$
\widehat{C}_{l}=-5938.34+815.65 \ln x_{1 i}
$$

Non-linear excl. Warsaw:

(4411.63) (348.08)

$$
\mathrm{R}^{2}=0.28
$$




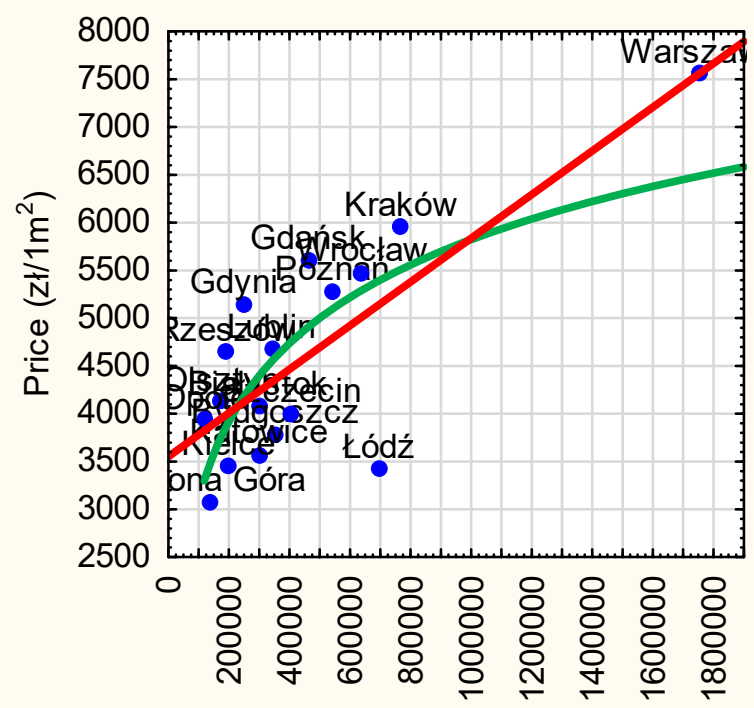

Population

Fig. 1. Collerogram price - population. Source: own study.

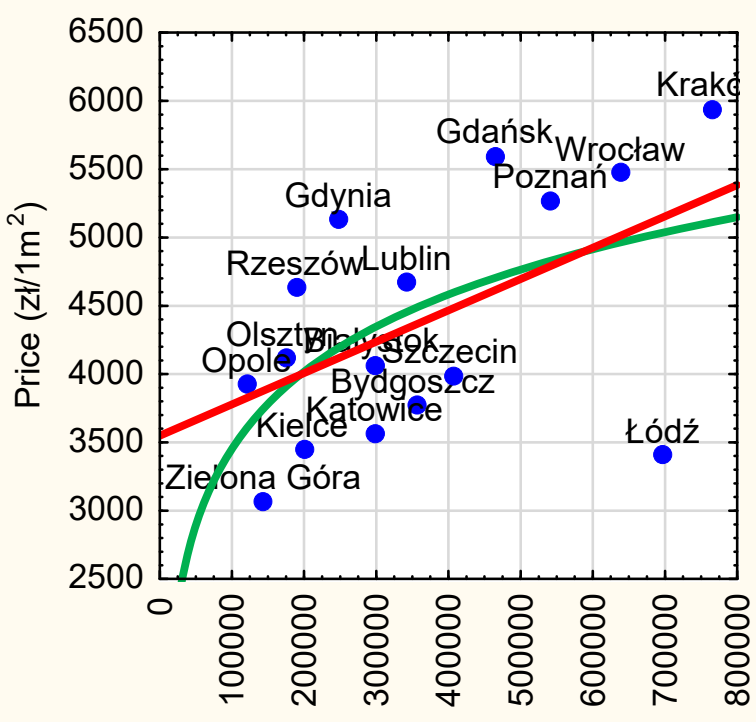

Population

Fig. 2. Collerogram price - population excl. Warsaw.

Source: own study.

The coefficient of correlation between the unit prices of apartments in cities and the size of the population is equal to 0.77 , which means that such correlation can be regarded as relatively strong. The analysis of collerograms provides grounds for claiming that the said relation is apparent generally the greater the population the higher the prices. However, it appears that, having excluded Warsaw, the relation visibly weakens, which is reflected by the correlation coefficient falling to 0.53 . For this reason, the relation between the size of the population and the prices of apartments can be regarded as moderate at the utmost. The estimated regression functions are poorly fitted to empirical data and, in the case of data excluding Warsaw, the fitting is so poor that the grounds for the usage of the function can be questioned. Non-linear functions describe the relation worse than linear functions. Moreover, for the non-linear function estimated for data excluding Warsaw, the intercept parameter is irrelevant (with relevance of 0.05 ).

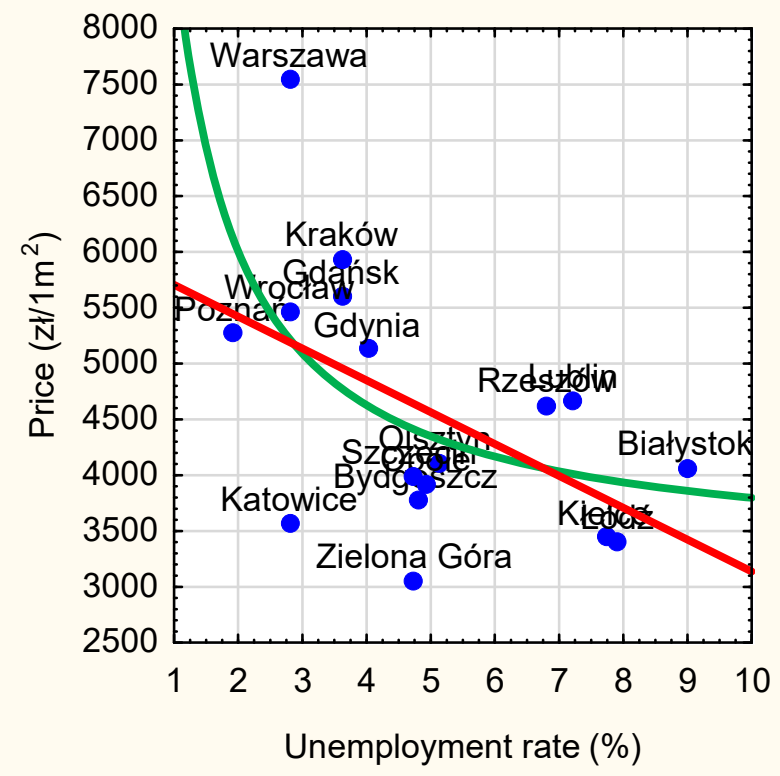

Fig 3. Collerogram price - unemployment rate. Source: own study.

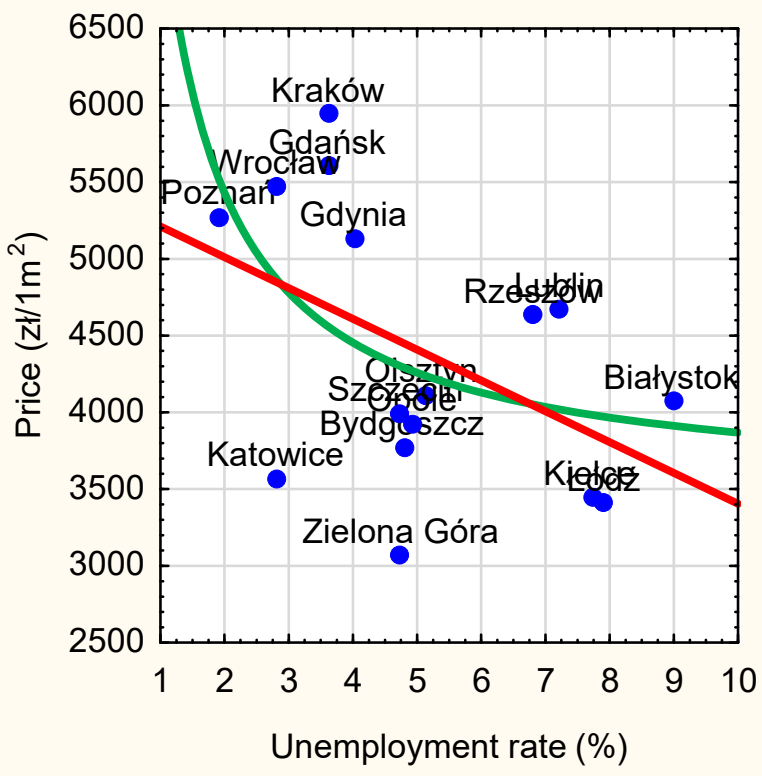

Fig. 4. Collerogram price - unemployment rate excl. Warsaw.

Source: own study. 
Regression functions:

Linear:

Linear excl. Warsaw:

Non-linear:

Non-linear excl. Warsaw:

$$
\begin{aligned}
\widehat{C}_{l}= & 5990.55-285.35 \cdot x_{2 i} & \\
& (655.56)(122.53) & \mathrm{R}^{2}=0.27 \\
\widehat{C}_{l}= & 5411.76-200.74 \cdot x_{2 i} & \\
& (552.64)(100.98) & \mathrm{R}^{2}=0.22 \\
\widehat{C}_{l}= & 3244.28+5532.19 / x_{2 i} & \\
& (605.67)(2302.16) & \mathrm{R}^{2}=0.28 \\
\widehat{C}_{l}= & 3477.69+3906.34 / x_{2 i} & \\
& (487.33)(1903.12) & \mathrm{R}^{2}=0.23
\end{aligned}
$$

Contrary to the prevalent belief, the prices of apartments in cities are not strongly correlated with unemployment levels. As regards data including all cities, the coefficient of linear correlation can be considered moderate because it comes to 0.52 and, having excluded Warsaw, it falls to 0.47 , which makes it statistically irrelevant. The estimated regression functions prove to be poorly fitted to the actual data, with non-linear functions slightly better fitted than linear functions. The exclusion of Warsaw makes the degree of fitting even worse. The correlation coefficients and direction parameters of linear functions are negative, thus proving that the relation is negative - the lower the unemployment rate, the higher the prices. In the linear and non-linear functions excluding Warsaw, direction parameters are statistically irrelevant.

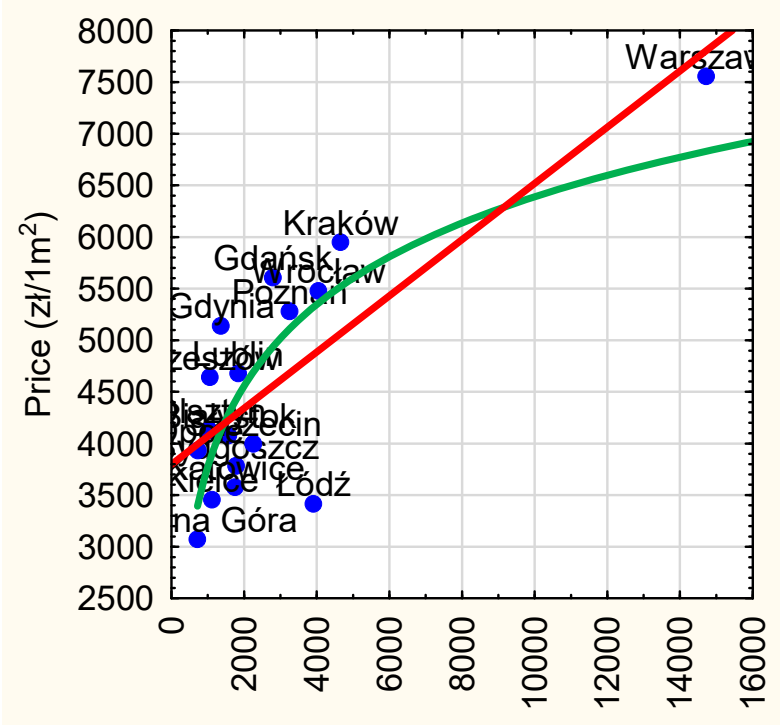

City revenues (million zł)

Fig.5. Collerogram price - city revenues. Source: own study.

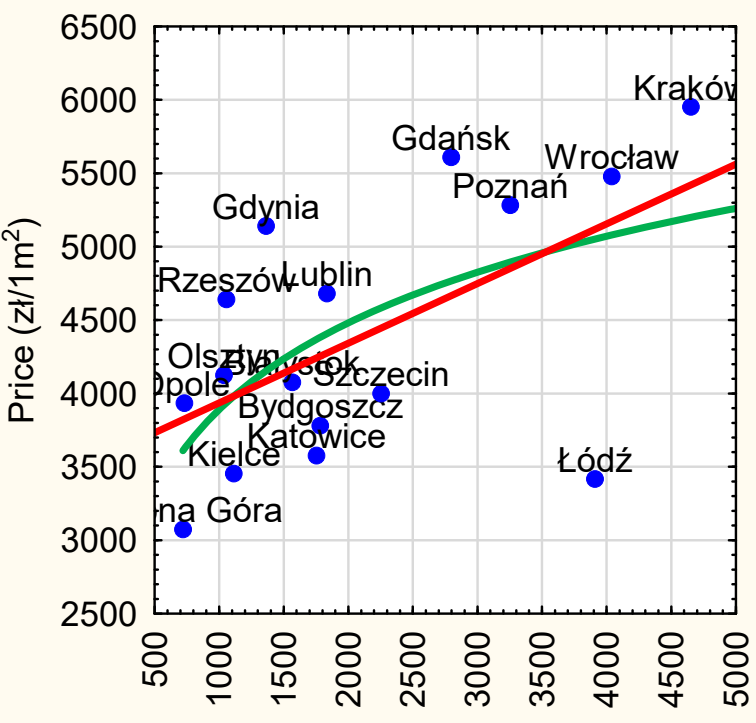

City revenues (million zł)

Fig 6. Collerogram price - city revenues excl. Warsaw. Source: own study.

Regression functions:

Linear:

Linear excl. Warsaw:

Non-linear:

Non-linear excl. Warsaw:

$$
\begin{array}{cc}
\widehat{C}_{l}= & 3797.52+0.27 x_{3 i} \\
& (242.78)(0.06) \\
\widehat{C}_{l}= & 3528.49+0.41 x_{3 i} \\
& (376.87)(0.15) \\
\widehat{C}_{l}= & -4100.20+2622.48 \log 10 x_{3 i} \\
& (1911.55)(575.06) \\
\widehat{C}_{l}= & -1994.40+1961.50 \log 10 x_{3 i} \\
& (2444.40)(748.83)
\end{array}
$$

The conducted studies point to a relatively strong dependence of the prices of apartments on city revenues - the correlation coefficient is equal to 0.78 . The collerogram clearly shows how much Warsaw differs from other cities in terms of this variable. Excluding the capital city from the data collection results in the coefficient dropping to 0.58 , which means that such correlation is in fact 
moderate. The estimated regression functions manifest not very high data fitting, which, after Warsaw is eliminated, is low, i.e. $\mathrm{R}^{2}=034$. This fitting is made even weaker, though slightly, by applying the studied relation of the non-linear functions. For the non-linear function excluding Warsaw, the intercept parameter is statistically irrelevant.

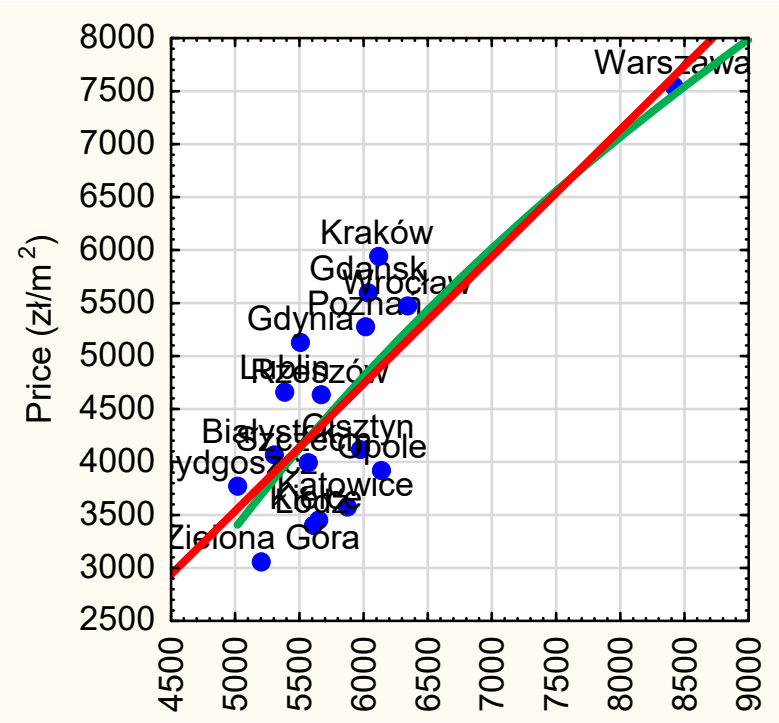

City revenues per person (zł)

Fig 7. Collerogram price - city revenues per person.

Source: own study.

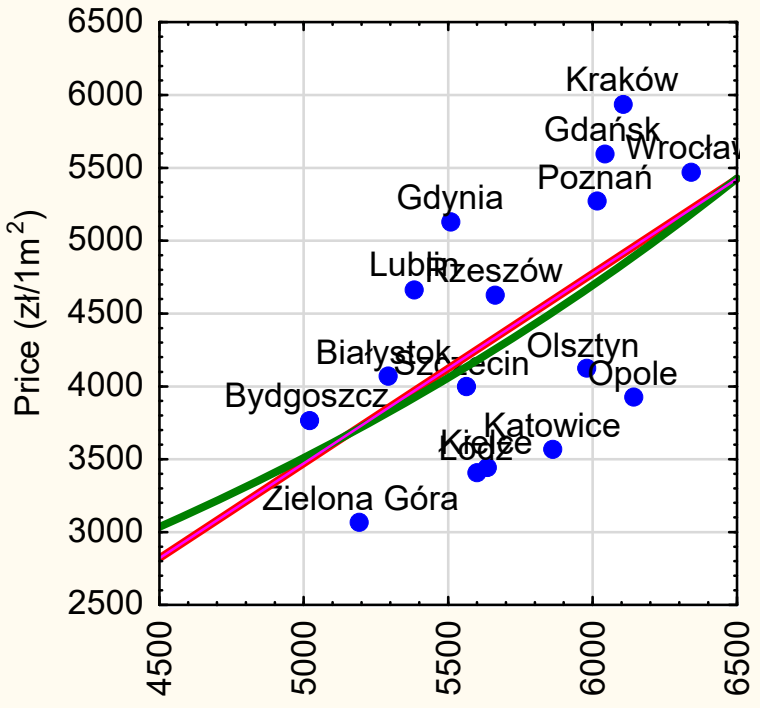

City revenues per person (zł)

Fig. 8. Collerogram price - city revenues per person excl. Warsaw. Source: own study.

Regression functions:

Linear:

Linear excl. Warsaw:

$\widehat{C}_{l}=-2455,49+1,20 \cdot x_{4 i}$

$(1443,87)(0,24)$

$\widehat{C}_{l}=-3040,65+1,30 \cdot x_{4 i}$

$(2968,86)(0,519)$

$\widehat{C}_{l}=-63467,02+18070,93 \log 10 x_{4 i}$

$(13944,45) \quad(3703,10)$

Non-linear:

$\widehat{C}_{l}=820,2433^{*} \exp \left(0,0003 x_{4 i}\right)$

$\mathrm{R}^{2}=0,62$

$\mathrm{R}^{2}=0,31$

$\mathrm{R}^{2}=0,61$

Non-linear excl. Warsaw:

$\mathrm{R}^{2}=0,30$

Also, the impact of city revenues per person on the prices of apartments seems significant as the correlation coefficient comes to 0.79 . This, however, is only on the face of it, because it is distorted by data of Warsaw differing in those terms from the other cities. When eliminating Warsaw data, the correlation coefficient falls to 0.56 . The estimated functions do not fit well to the empirical data, both when applying the linear and non-linear analytical form of the regression function and, if Warsaw data are excluded, the determination coefficient drops to $0.30-0.31$, thus proving the limited value of these functions in identifying the studied relation. For the linear function, estimated both based on data including Warsaw and excluding Warsaw, the intercept parameter is irrelevant.

Regression functions:

Linear:

$$
\begin{aligned}
\widehat{C_{l}}= & 3677.99+4.19 \cdot x_{5 i} \\
& (268.00)(0.91) \\
\widehat{C}_{l}= & 3655.63+4.33 \cdot x_{5 i}
\end{aligned}
$$

$\mathrm{R}^{2}=0.59$

Linear excl. Warsaw:

(376.87) (1.97)

$\mathrm{R}^{2}=0.26$

$\mathrm{R}^{2}=0.51$

$\widehat{C}_{l}=-944.18+2509.12 \log 10 x_{5 i}$

(1401.26) (630.39)

$\mathrm{R}^{2}=0.51$

$\widehat{C}_{l}=672.15+1727.49 \log 10 x_{5 i}$

(1608.09) (741.87)

$\mathrm{R}^{2}=0.28$ 


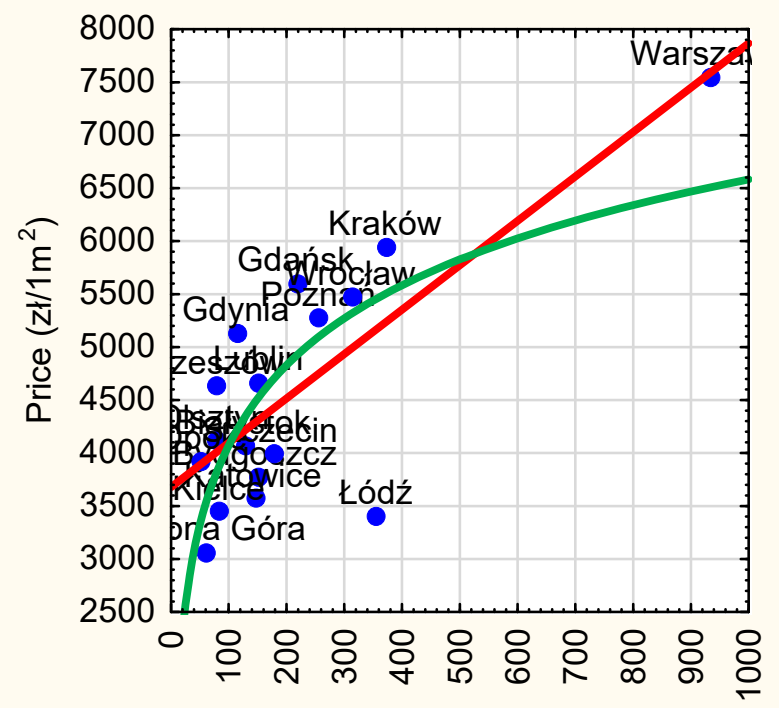

Number of apartments (thousand)

Fig 9. Collerogram price - number of apartments. Source: own study.

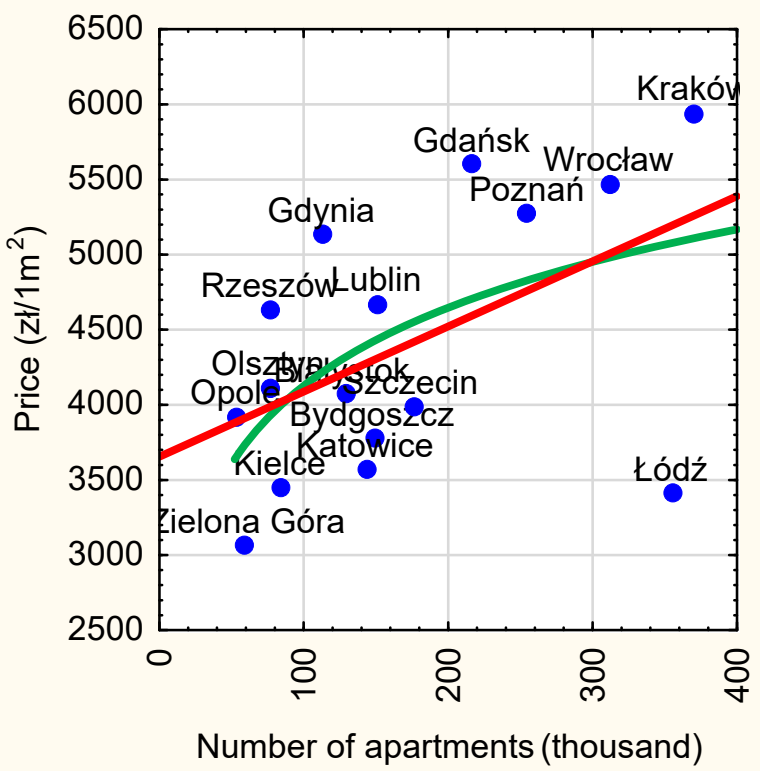

Fig 10. Collerogram price - number of apartments excl. Warsaw.

Source: own study.

Similar conclusions can be drawn from analyzing the impact of the number of apartments in respective cities on the level of prices of apartments recorded in those cities. High correlation between these variables is the effect of unusually high values thereof recorded in Warsaw. When Warsaw is eliminated, the coefficient of correlation falls to 0.56 . The estimated regression functions, even based on data including Warsaw, do not demonstrate high fitting; however, the linear function including Warsaw shows a slightly better fitting than the non-linear function and, in the case of data excluding Warsaw, a slightly better fitting - compared to the linear function - is demonstrated by the logarithmic function, though it cannot go unnoticed that such fitting is very low. Intercept parameters of non-linear functions are irrelevant both for data including Warsaw and data excluding Warsaw.

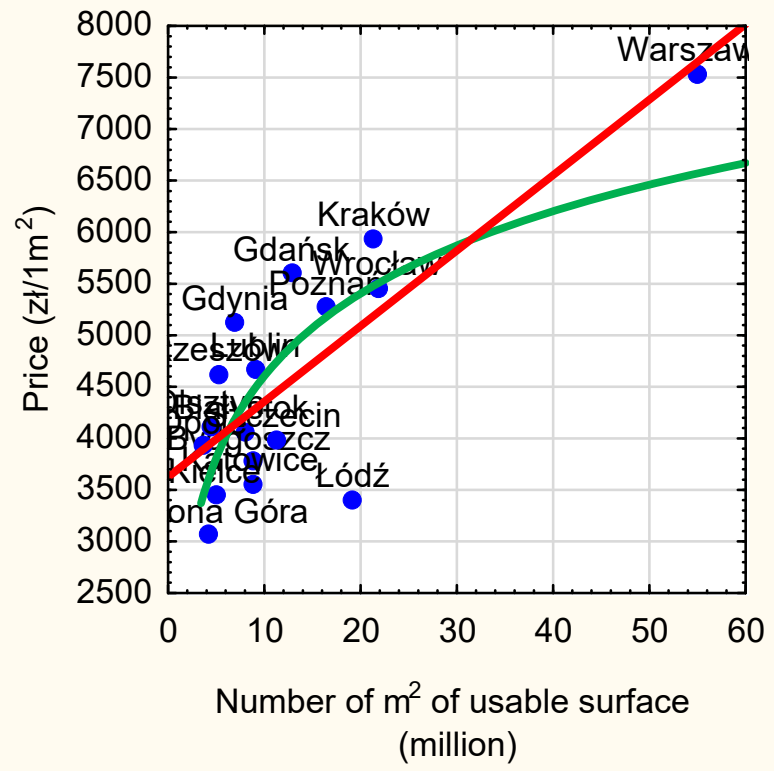

Fig. 11. Collerogram price - number of $m 2$ of usable surface.

Source: own study.

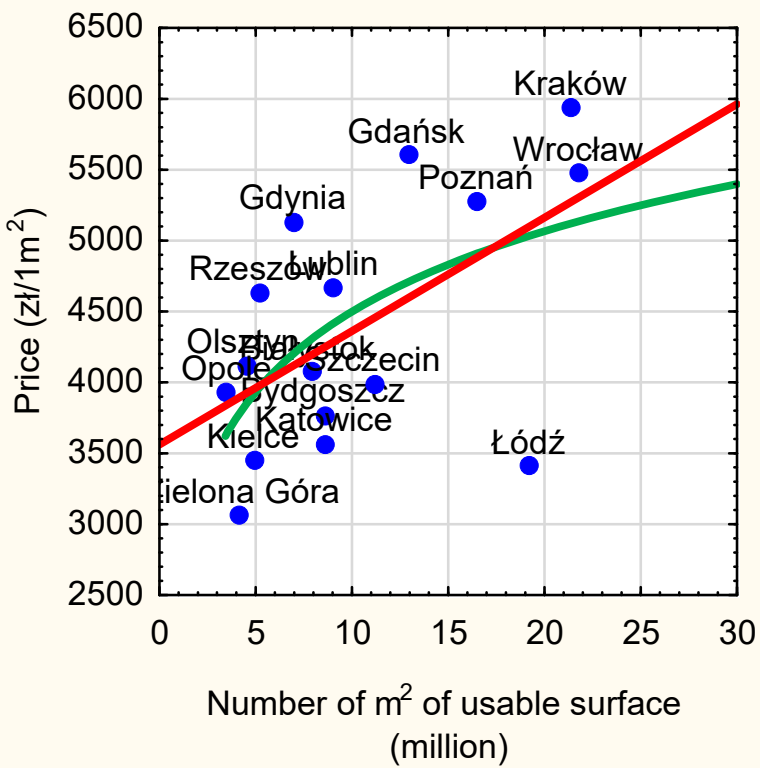

Fig. 12. Collerogram price - number of $\mathrm{m} 2$ of usable surface excl. Warsaw.

Source: own study. 
Linear:

Linear excl. Warsaw:

Non-linear:

Non-linear excl. Warsaw:

$$
\begin{aligned}
\widehat{C_{l}}= & 3626.63+73.17 \cdot x_{6 i} \\
& (262.12)(14.84) \\
\widehat{C}_{l}= & 3560.90+80.06 \cdot x_{6 i}
\end{aligned}
$$$$
\text { (377.76) (31.59) }
$$

$\widehat{C}_{l}=1950.27+2654.63 \log 10 x_{6 i}$

(654.89) (632.07)

$\widehat{C}_{l}=2612.71+1885.90 \log 10 x_{6 i}$

(732.43) (750.89)

$$
\begin{aligned}
& R^{2}=0.62 \\
& R^{2}=0.31 \\
& R^{2}=0.54 \\
& R^{2}=0.31
\end{aligned}
$$

The number of square metres of the usable surface of the apartments is a variable strongly related to the number of apartments. Similar conclusions follow from the analysis of the impact of this variable on the unit prices of apartments, though the estimated regression functions in all variants prove better fitting and all structural parameters of those functions are statistically relevant. For this reason, it is reasonable to argue that the usable surface of apartments expresses the size of city housing resources more precisely as compared to the number of apartments, at least for the purpose of estimating the impact of these resources on the prices of apartments. Nevertheless, this does not change the fact that the fitting of respective functions to empirical data is still unsatisfactory.

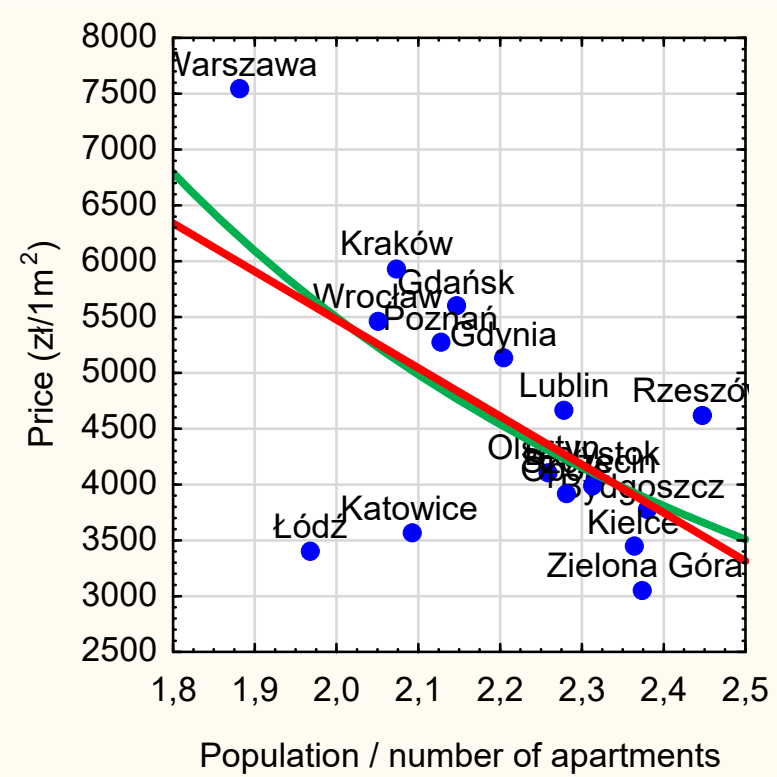

Fig. 13. Collerogram price - population/number of apartments.

Source: own study.

Linear:

Linear excl. Warsaw:

Non-linear:

Non-linear excl. Warsaw:

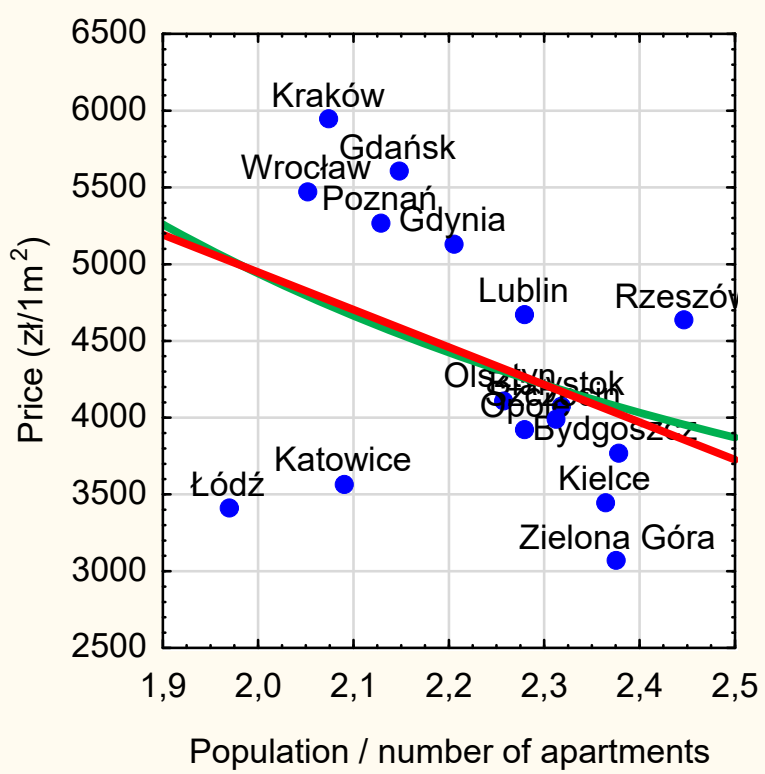

Fig. 14. Collerogram price - population/number of apartments excl. Warsaw. Source: own study.

$$
\begin{array}{rrr}
\widehat{C}_{l}=14117.96-4321.56 \cdot x_{7 i} & \\
(3320.29)(1500.04) & \mathrm{R}^{2}=0.36 \\
\widehat{C}_{l}=9834.69-2443.48 \cdot x_{7 i} & \\
(3504.22)(1569.56) & \mathrm{R}^{2}=0.15 \\
\widehat{C}_{l}=\begin{array}{r}
26.42+22094.63 / x_{7 i}{ }^{2} \\
(1554.28)(7381.62)
\end{array} & \mathrm{R}^{2}=0.37 \\
\widehat{C}_{l}=\begin{array}{r}
1972.24+11869.49 /\left(x_{7 i}\right)^{2} \\
(1729.63)(8428.46)
\end{array} & \mathrm{R}^{2}=0.12
\end{array}
$$

Another factor taken into consideration is the number of individuals per house (population/number of houses). It seems that poorer housing conditions of the population expressed in this manner should have a demand-stimulating impact and thus, also a pro-price effect on the property market. However, a negative and at the same time weak relation is in fact observed; as regards Warsaw, the correlation coefficient is -0.60 , but if Warsaw is excluded - the coefficient is statistically irrelevant and equal to -0.38. The estimated regression functions are also poorly fitted to empirical data. In the linear function with Warsaw excluded the directional parameter is irrelevant, and in the non-linear function, it is the intercept parameter that is irrelevant. As regards data excluding Warsaw, both parameters are irrelevant in the non-linear function. Thus, it can be argued 
that housing density is not an apartment prices factor.

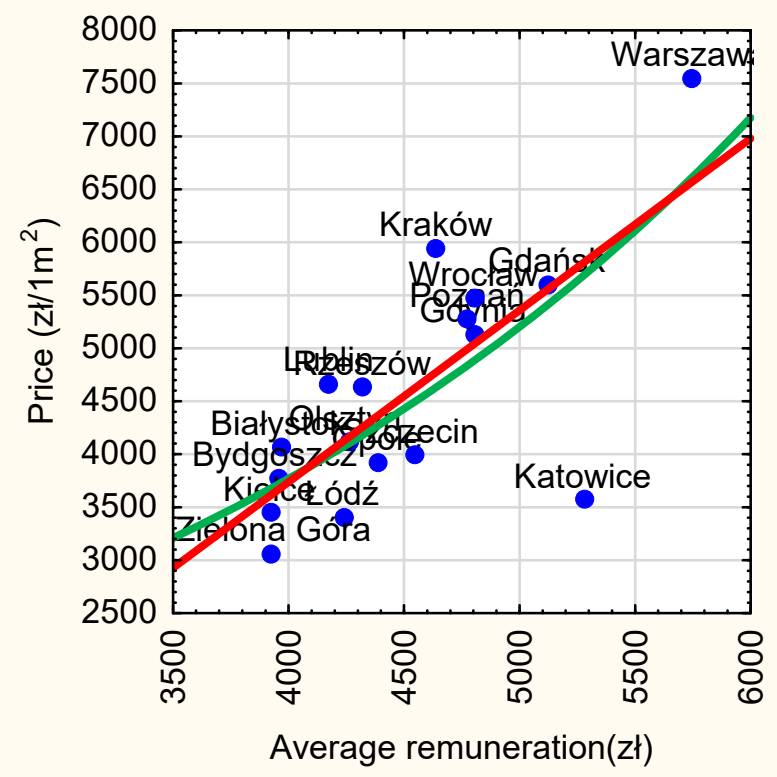

Fig. 15. Collerogram price - average remuneration. Source: own study.

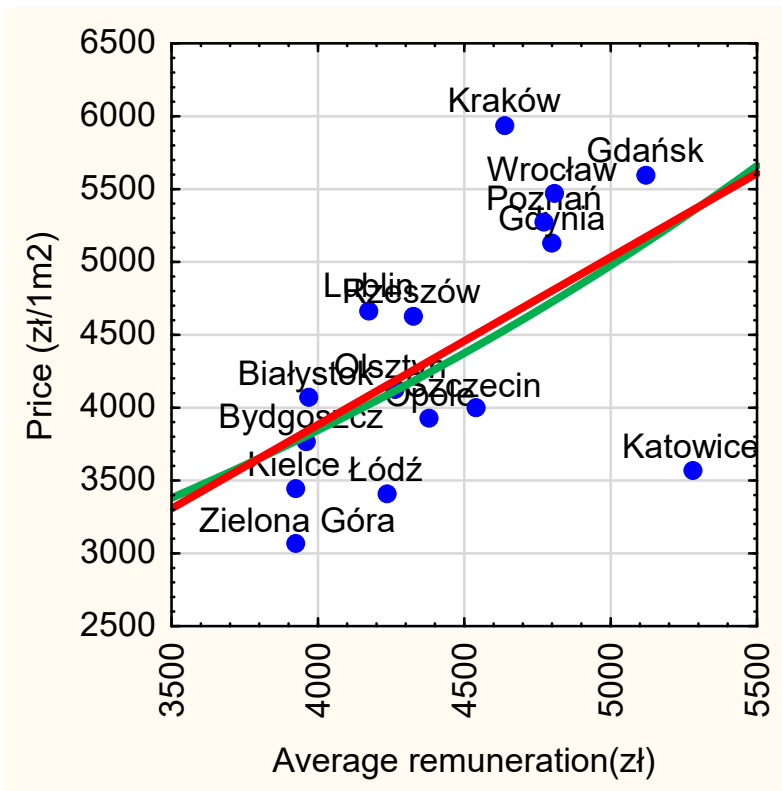

Fig. 16. Collerogram price - average remuneration excl. Warsaw Source: own study.

\section{Linear:}

Linear excl. Warsaw:

Non-linear:

Non-linear excl. Warsaw:

$$
\begin{array}{cc}
\widehat{C}_{l}=-2752.39+1.62 \cdot x_{8 i} & \mathrm{R}^{2}=054 \\
(1761.08)(0.39) & \\
\widehat{C}_{l}=-720.77+1.15 \cdot x_{8 i} & \mathrm{R}^{2}=0.31 \\
(2046.39)(0.4590) & \\
\widehat{C}_{l}=1040.21 \exp \left(0.0003^{*} x_{8 i}\right) & \mathrm{R}^{2}=0.54 \\
\widehat{C}_{l}=3370.52 \exp \left(0.000061842 x_{8 i}\right) & \mathrm{R}^{2}=0.31
\end{array}
$$

Average remuneration is the last factor considered. The fact that it was considered in the survey was motivated by the notion that the greater the income that potential buyers have, the higher the housing prices which they are ready to accept, as shown on the market. However, it appears that the impact of the said factor on the prices is comparable to other factors characterizing the size and wealth of the urban area. Moreover, attention should be given to the fact that, among factors characterising the affluence and life quality of residents (unemployment rate, number of individuals per house, average remuneration), only average remuneration demonstrates comparability - in terms of its relation power - with factors of the other groups.

Nonetheless, similarly as in the case of other factors, the quality of the estimated functions leaves much to be desired and eliminating Warsaw only weakens it. The intercept parameter in the linear function both with and without Warsaw is irrelevant. Since relations between the specified factors have been found to be relatively poor or moderate at the very most, no attempt was made to estimate the function of multifarious regression of the average unit house price in respective cities in relation to all social \& economic factors, as well as the function of multifarious regressions of the average unit price of houses in respective cities vs. chosen groups of factors.

\section{Summary and conclusions}

Identification of social \& economic factors underlying apartment prices in chosen cities in Poland appears to be a difficult problem. Simple statistical methods such as correlation and regression do not produce satisfactory results in this case. The conducted surveys provide grounds for the following conclusions:

1. the proposed factors influence the house prices to a moderate extent,

2. eliminating Warsaw as a significantly different city compared to others in terms of all factors weakens the relations of those factors with apartment prices in respective cities,

3. a somewhat greater impact on the prices is beared by factors that characterise the size of the city 
and its wealth rather than factors characterizing the quality of life of its inhabitants, except for average remuneration.

When analyzing collerograms, it can be concluded that some cities are relatively often characterized by a variable corresponding to a particular factor at a level significantly diverging from other cities of similar house prices. These cities include Łódź. Less often, the role of outsiders was played by Katowice and Zielona Góra.

Eliminating certain cities from the data collection in respective cases may be expected to strengthen the studied relations and improve the quality of the estimated functions. However, a question arises whether this is the right way to seek factors underlying apartment prices? By acting in line with this rule, the resulting conclusions will be unambiguous but each time applicable to a sufficiently good group of cities. Among dozens of cities taken into consideration, when analysing the impact of particular factors on apartment prices, it would always be possible to choose such a group of cities to be able to define the relations as strong. But would those still be the factors underlying apartment prices in Poland? It seems that surveys ought to be continued on a multipath basis, in particular by:

- Looking for other factors - besides those considered in the survey - underlying property prices, in particular prices of apartments. Perhaps factors such as the age structure or education of the population or even the prestige of the city, etc. may prove to be significant factors;

- Studying the impact of groups of relevant factors on apartment prices in cities rather than factors examined individually;

- Examining the role of the anchoring effect with regard to property prices and its impact on the current prices of real estate (SHAHAR GOLAN 2017).

\section{References}

BALl M., Lizieri C., MACGRegor B.D., 1998, The Economics of Commercial Property Markets, Routledge, London,

Ben-ShaHaR, D. Golan, R. (2017), Anchoring under Currency Substitution: A Ratchet Price Mechanism in the Housing Market. Real Estate Economics, 45: 861-897,

Black, A., P. Fraser AND M. Hoesli. 2006. House Prices, Fundamental and Bubbles. Journal of Business Finance and Accounting 33: 1535-1555,

CAPOzZA D.R., HendershotT P.H., MACK C., MAYER C.J., 2002, Determinants of Real House Price Dynamics, Working Paper 9262, National Bureau of Economic Research, Cambridge,

Egert B. MinaljeK D., 2007, Determinants of House Prices in Central and Eastern Europe, BIS Working Papers No 236, Bank for International Settlements, Monetary and Economic Department,

FORYŚ I., 2013, Społeczno-gospodarcze determinanty rozwoju rynku mieszkaniowego w Polsce (Social and Economic Determinants of the Housing Market Development in Poland) Wydawnictwo Naukowe Uniwersytetu Szczecińskiego, Szczecin (Scientific Publisher of the University of Szczecin),

Hwang M, Quigley J.M. (2006) Economic Fundamentals in Local Housing Markets: Evidence from U.S. Metropolitan Regions. Journal of Regional Science, 46, 425-53,

KuCHARSKA STASIAK E., 2006, Nieruchomość w gospodarce rynkowej (A Real Estate in a Market Economy) Wydawnictwo Naukowe PWN (PWN Scientific Publisher) Warszawa,

LaI, R. N. AND VAN ORDER, R. (2017), U.S. House Prices over the Last 30 Years: Bubbles, Regime Shifts and Market (In)Efficiency. Real Estate Economics, 45: 259-300,

ŁACH Ł. 2014, Czynniki ksztattujące wartość nieruchomości mieszkaniowych w kontekście uwarunkowań makro-, mikro oraz ultraotoczenia (Factors Determining the Value of Real Esate in Macro, Micro and Ultra Environment, Publisher of the Wroclaw University of Economics) Ekonometria (Econometrics) No. 4(46) Wydawnictwo Uniwersytetu Ekonomicznego we Wrocławiu (Publishing House of the Wrocław University of Economics),

RĄCKA I., PALICKI S., KRAJEWSKA M., SZOPIŃSKA K., KeMPA O., 2017, Changes On the Housing Market of the Downtown Area in Selected Polish Cities, Real Estate Management and Valuation, Vol. 25, Issue 2,

STACHURA E., 2007, Marketing na rynku nieruchomości (Marketing on the Real Estate Market) Polskie Wydawnictwo Ekonomiczne (Polish Economics Publishing House), Warszawa,

Strobel, J., NGuyen Thanh, B. AND LeE, G. (2018), Effects of Macroeconomic Uncertainty and Labor Demand Shocks on the Housing Market. Real Estate Economics,

WiŚNIEWSKA M.A., 2011, Inwestowanie w nieruchomości na rynkach międzynarodowych (Investing in Real Estate on International Markets) Wydawnictwo Naukowe PWN (PWN Scientific Publisher), Warszawa. 